Scholarship Repository

University of Minnesota Law School

Articles

Faculty Scholarship

1992

\title{
Salvaging the Sentencing Guidelines in Seven Easy Steps
}

Michael Tonry

University of Minnesota Law School, tonry001@umn.edu

Follow this and additional works at: https://scholarship.law.umn.edu/faculty_articles

Part of the Law Commons

\section{Recommended Citation}

Michael Tonry, Salvaging the Sentencing Guidelines in Seven Easy Steps, 4 FED. SENTENCING R. 355 (1992), available at https://scholarship.law.umn.edu/faculty_articles/520.

This Article is brought to you for free and open access by the University of Minnesota Law School. It has been accepted for inclusion in the Faculty Scholarship collection by an authorized administrator of the Scholarship Repository. For more information, please contact lenzx009@umn.edu. 


\section{SALVAGING THE SENTENCING GUIDELINES IN SEVEN EASY STEPS}

\author{
Michael Tonry*
}

The federal sentencing guidelines are salvageable, and without repeal or amendment of the Sentencing Reform Act of 1984. Many people appear to believe that the only sentencing policy options for the federal courts are retention of the current guidelines substantially as is or repeal of the Sentencing Reform Act. This belief, which is mistaken, is encouraged by the U.S. Sentencing Commission. In its December. 1991 report on its self-evaluation of the first four years guidelines experience, for example, the Commission attributes opposition to the guidelines to

"resistance... on the part of some federal judges and others involved in the sentencing process to the need for and wisdom of the statutory scheme for sentencing reform enacted by Congress in the 1984 Sentencing Reform Act." 1

If the Commission were right, if the only choices were between the current guidelines and statutory repeal, judges' despair about the guidelines would be warranted; outright repeal of the Act in the foreseeable future appears unlikely. However there is another choice, a middle ground. Under the existing legislation, many of the Commission's policy decisions could have been otherwise. Guidelines could have been, and still can be, fashioned that would reduce sentencing disparities but not routinely require judges to impose sentences that they consider unjust. Other sentencing commissions faced the issues that the Commission faced, and arrived at different policy conclusions. If the Commission were now to look at and learn from experience elsewhere, it could remedy many of the guidelines' current problems.

Many features of the current guidelines that judges find most objectionable result not from the requirements of the Sentencing Reform Act of 1984 but from the Commission's policy decisions. This article describes seven such decisions that could have been made otherwise and that together produce the combination of rigidity and harshness that have driven many judges and prosecutors to resent the guidelines and often to circumvent them. Below I discuss those decisions and other, more palatable, options that were available to that the Commission:

1. giving the prosecutor sole discretion to decide when defendants are eligible for sentence reductions for substantial assistance to the government (Guidelines, Sect. 5K1.1);

2. nullifying the statutory presumption (Sect. 99(j)) against imprisonment of first offenders

* Sonosky Professor of Law and Public Policy, University of Minnesota. "not convicted of a crime of violence or an otherwise serious offense" by defining as "serious" many offenses that typically received probation before the guidelines took effect; 3. treating sentences to probation as "zero months imprisonment" and thereby triggering statutory Section $994(b)(2)$ 's provision that "if a sentence specified by the guidelines includes a term of imprisonment," the top of the guideline range may not exceed the bottom by the greater of 25 percent or 6 months;

4. adopting "relevant conduct" as the basis for applying guidelines rather than the offense of conviction;

5. providing guidelines only for imprisonment and, to a much lesser extent than before the guidelines took effect, probation; there are no guidelines for fines as stand-alone sanctions or for any intermediate punishments;

6. raising sentencing severity generally, in order to incorporate mandatory penalty provisions into the grid, rather than having the mandatories operate as trumps;

7. adopting a 43-level sentencing grid which inevitably looks like a sentencing machine, arbitrary, impersonal, and mechanical, and reduces the credibility of the guidelines in the eyes of judges and others.

None of these decisions was required by the Act. Except for the decision to incorporate mandatory penalties into the guidelines, none of them necessarily implies greater or lesser severity in sentences. They are simply technical or technocratic decisions that the Commission made, that it could have made otherwise, and that can today be changed. Of the seven decisions, the first three involve statutory interpretations; the rest involve what might be called the architecture of sentencing guidelines. Most involve issues that have confronted sentencing commissions in Canada, Minnesota, Oregon, Pennsylvania, and Washington.

I. Substantial Assistance Motions. The Commission, not the Congress, conditioned sentence reductions for assistance to the government on prosecutorial motions. Statute section 994(n) directs the Commission to "assure that the guidelines reflect the general appropriateness [of sentence reductions] to take into account a defendant's substantial assistance in the investigation or prosecution of another person who has committed an offense." Although the statute says nothing to suggest that the prosecutor should have sole authority to decide when and whether substantial assistance has been provided, Guidelines Section 5K1.1 provides: "upon motion of the government stating that the defendant has provided substantial assistance ... the court may depart from the guidelines."

By amending Section 5K1.1 to substitute the word "when" for the words "upon motion of the govern- 
ment stating that," the Commission would be acting consistently with the statute and would empower judges to exercise independent judgment when controversies arise as to whether assistance has been provided and, if so, whether it has been substantial.

II. The First-offender Nonincarceration Presumption. As a result of its express policy decision to increase the use of incarceration, the Commission largely overrode a statutory presumption that nonviolent first offenders should receive nonincarcerative sentences. Statute Section 994(j) directs the Commission to "insure that the guidelines reflect the general appropriateness of imposing a sentence other than imprisonment in cases in which the defendant is a first offender who has not been convicted of a crime of violence or an otherwise serious offense." Confronted by its own empirical research showing that many first offenders were sentenced to probation before the guidelines took effect, ${ }^{2}$ which the Commission described as a "problem," the Commission devised its own definition of "serious." Here is how the Commission describes what it did: "The Commission's solution to this problem has been to write guidelines that classify as serious many offenses for which probation previously was given and provide for at least a short period of imprisonment in such cases." (Guidelines Introduction, Section 4(c))

The Commission's rationale for overriding the Congressional presumption was that the courts had in the past ordered probation for "inappropriately high percentages" of white collar offenders, including such crimes as "theft, tax evasion, antitrust offenses, insider trading, fraud, and embezzlement." The weakness in this rationale is that it did not reflect the real world of the federal courts. Antitrust, insider trading, and tax evasion represent a small percentage of offenders who received probation before the guidelines took effect. The people who were hurt, swept into the Commission's "white collar" net, were people convicted of immigration offenses, minor postal thefts and property crimes, low-level bank-teller embezzlers, and others who bear no discernible resemblance to Ivan Boesky, Leona Helmsley, or Michael Milken. Thus when the Commission overrode the first-offender presumption language, it did so on a false policy premise.

An easy solution, well within the authority of the Commission, is available. Even if the current guidelines were changed in no other respect, the Commission could add a new section to Part $K$ of the guidelines providing:

If the defendant is a first offender who has not been convicted of a crime of violence or an otherwise serious crime, the court may depart from the guidelines in order to impose a sentence other than imprisonment.

The proposed language tracks Section 994(j)'s statutory language and would allow the trial and appellate courts to determine when nonviolent first offenses are otherwise so serious that the nonincarceration presumption is overcome.
III. Probation as "Zero Months Imprisonment." A third critical choice made by the Commission that had radical consequences and was not required by Congress concerned the seemingly innocuous and for most purposes entirely theoretical question whether probation is a generically different kind of sentence from imprisonment or whether a sentence to probation is a sentence of "zero months imprisonment". The Commission took the second position and thereby eliminated probation as a stand-alone sentence for all but the most trifling crimes. This seemingly obscure conceptual point was made important by statute Section 994(b)(2) which provided: "if a sentence specified by the guidelines includes a term of imprisonment, the maximum of the range established for such a term shall not exceed the minimum of that range by more than the greater of 25 percent or six months."

If probation is not a sentence of zero months imprisonment, Section $994(\mathrm{~b})(2)$ has no relevance. A guideline could, for a specific offense/criminal history combination, specify authorized sentences ranging from probation to a prison sentence up to 24 or 36 months. If, however, probation is a zero months prison sentence, then Section 994(b)(2) applies and a maximum range of " 0 to 6 months" is the result.

Little can be said in favor of the Commission's decision that probation is a form of imprisonment; it required a tortured interpretation of words whose contrary conventional meaning is clear. The common understanding is that probation is a different form of punishment, one that judges often consider as an alternative for imprisonment. The Commission's interpretation is conceptually muddled; if fines were permitted by the guidelines as stand-alone punishments, the Commission would presumably define a fine as a sentence of zero months incarceration. Whether that would be more forced than so regarding probation I don't know, but it is exactly the same issue. For both fines and probation, prison exists as a backup to be used when offenders fail to comply with conditions; in both cases, when conditions are observed, offenders are entitled to absolute discharges. The Commission's interpretation is also inconsistent with the firstoffender nonimprisonment presumption because it narrows the relevance of that presumption to a tiny fraction of federal offenders.

IV. "Real Offense Sentencing." The single feature of the federal sentencing guidelines that state judges and judges and judicial administrators outside the United States find most astonishing is the Commission's policy decision to base guideline application on the defendant's "relevant conduct," including conduct alleged in charges that were dismissed or that resulted in acquittals or that were never filed. More than once when describing the relevant conduct system to government officials and judges outside the United States, I have been accused of misreporting or exaggerating.

Every sentencing guidelines commission to date has considered whether to adopt a "relevant con- 
duct" or "real offense" approach as a means to offset prosecutorial power to influence guideline sentencing by decisions about charges to file or drop. The potential problems posed by plea bargaining under guidelines are real. Nonetheless, the sentencing commissions in Canada, Minnesota, Oregon, Pennsylvania, and Washington unanimously rejected real offense sentencing and based guidelines on convicted offenses.

Real offense sentencing has been unanimously rejected elsewhere for two primary reasons. First, there is the Caesar's wife problem that courts must not only do justice but be seen to do justice. Even though prosecutorial power under guidelines has everywhere been seen as a potential problem, adoption of a system that divorces punishment from the substantive criminal law, the law of evidence, and the requirement of proof beyond a reasonable doubt has everywhere been seen as a bigger and much more important problem. Second, other sentencing commissions have been doubtful that real offense sentencing would be an effective counter to prosecutorial power. Experience under the federal guidelines confirms that skepticism: probably the single most common judicial complaint about the guidelines is that they have shifted sentencing power to the prosecutor. ${ }^{3}$

The Commission offered three major reasons for adopting the relevant conduct approach, all demonstrably mistaken or misconceived. The first, that real offense sentencing would prevent a shift of power to the prosecutor, has been discussed.

The second, exemplified by Williams $v$. New York, 337 U.S. 241 (1949), is that judges have authority to look beyond the conviction offense and have always done so. The problem with this argument is that Williams was decided in the heyday of indeterminate sentencing when judges were expected to individualize sentences; the guidelines, however, are a form of determinate sentencing which is premised on the notion that judges' discretion should be more narrowly constrained than in the era of indeterminate sentencing. Thus, modern case law to the contrary notwithstanding, the rationale of Williams has little relevance to modern determinate sentencing.

The third was that the federal criminal law is incomparably more complex than are state criminal laws and that many federal offenses in their labels and elements provide no meaningful basis for measuring culpability. Mail and wire fraud and RICO offenses are examples. If a majority of federal offenders were convicted of mail fraud, the Commission's point might have been well taken. In practice, however, drug crimes make up roughly half of the federal criminal docket and much of the rest consists of common law crimes like theft, robbery, and embezzlement, and conceptually uncomplicated crimes like immigration offenses. ${ }^{4}$ Thus modern federal criminal cases look much like state cases and there is no more need for real offense sentencing in the federal system than in the states.

There is no statutory mandate for real offense sentencing. The Commission has authority to switch to an offense-of-conviction system and could do so in ways that address some of the concerns that underlay their relevant conduct approach. To deal with the problem of statutes that are too generically phrased, the Commission could add additional elements (firearms use, violence) to divide broadly defined offenses into subcategories of different seriousness and by rule require that the prosecutor allege those additional elements and that they be proven beyond a reasonable doubt or admitted. That is how Minnesota, Washington, and Pennsylvania handled this problem. To deal with exotic federal crimes like mail fraud and RICO, the Commission could establish special rules.

V. No Place for Intermediate Punishments. The federal guidelines allow no independent role for intermediate punishments like fines, house arrest, intensively supervised probation, or community service. The only free-standing sentences authorized are prison and probation (and, as noted earlier, the role allotted probation is limited).

Fines as independent sentences are conspicuously absent. Although the Congress's first charge to the Commission in statute Section 994(a)(1) was to promulgate "guidelines for use by the court in determining the sentence to be imposed. . . including $(A)$ a determination whether to impose a sentence to probation, a fine, or a term of imprisonment," fines are nowhere authorized as a sole sentence for individuals. Instead, Guidelines Section 5E1.2(a) provides: "the court shall impose a fine in all cases, except [when the defendant lacks ability to pay]." Thus fines are available as add-ons to prison sentences or probation, but not as punishments in their own right.

Nor do the guidelines authorize other nonincarcerative sanctions as independent sentences. Guidelines Part F (Sections 5F1.1-3) authorize community confinement, home detention, and community service, but only "as a condition of probation or supervised release." The guidelines make no mention of intensively supervised probation, which is widely used in American states as an alternative to imprisonment.

The absence of any provision in the guidelines for imposition of fines and other nonincarcerative intermediate punishments is remarkable. Many federal crimes are especially appropriate for fines. In many Western countries, the fine is the single most often imposed punishment for many offenses including even some violent offenses. The "day-fine," calibrated both to the seriousness of the crime and to the defendant's means, provides a tested mechanism for use of fines in serious cases. Reasonable people can differ whether in principle a fine is an appropriate sentence for, say, a serious assault; it is hard to see how reasonable people can disagree that there are some nontrivial crimes for which fines-which can serve both deterrent and punitive purposes-are uniquely suited. It won't do for the Commission to respond that fines can be coupled with probation 
sentences, making a de facto stand-alone fine, because the Commission restricted probation to only a small proportion of federal defendants convicted of minor crimes.

Similarly, there is much experience in the United States and Western Europe with intermediate punishments which the Commission could have drawn on in setting guidelines for such punishments. Sentencing commissions in Oregon, Pennsylvania and Washington are incorporating intermediate punishments into their guidelines. A Commission task force headed by Commissioner Helen Corrothers offered concrete proposals for building intermediate punishments into the guidelines so that judges would have more options for better tailoring sentences to meet the circumstances of individual defendants. ${ }^{5}$ The Commission has not acted on any of the Corrothers committee's major recommendations.

Had it the will, the Commission could easily incorporate fines and intermediate punishments into the federal guidelines. The state sentencing commissions have accumulated substantial experience on this subject. There is a sizable scholarly literature. ${ }^{6}$ Within a few months, the Commission could devise guidelines for fines and other punishments scaled to offense severity that judges could use in lieu of otherwise-applicable prison sentences of up to three years duration.

VI. Mandatory Penalties as "Trumps." The Commission knowingly increased sentences for many crimes by the way it handled mandatory penalties. There are two ways to reconcile mandatories and guidelines; every other sentencing commission to date considered those options and every other commission chose the option the Commission rejected.

Here is the problem. Mandatory penalty provisions often call for minimum terms longer than past practice and longer than a sentencing commission as an independent body would prescribe. There are two ways to handle this. The first is to develop a comprehensive set of guidelines based on knowledge of past practices and conscious policy decisions to change past practice. If mandatory minimum statutes require longer sentences than the guidelines prescribe in individual cases, policy statements can instruct the judge that the mandatory minimum statute takes precedence and trumps the guidelines. This approach, which every state sentencing commission adopted, has the advantage that it makes clear when sentences uniquely result from application of mandatory penalty statutes.

The other approach is to incorporate the statutory minimums into the guidelines and scale all other penalties around the mandatories. This has the effect of increasing the severity of guideline sentences generally. A metaphor shows why. Imagine a sentencing guidelines grid as a lattice. Under the mandatories-as-trumps approach, long minimum sentences poke through the lattice and when they are very long, tower above it. Under the Commission's approach, the entire lattice is lifted, as if the manda- tory minimums were posts, and the sentences for many crimes not covered by the mandatory provisions are lifted also.

Here, too, there is an easy way to salvage the federal guidelines: merely follow the lead of every other sentencing commission and shift to the mandatories-as-trumps approach.

VII. The 43-Level "Sentencing Machine." One of the Commission's worst blunders was promulgation of the 43-level sentencing table in Chapter 5, Part A. By being so large and giving an appearance of arbitrary sentencing by numbers, it became one of the guidelines' worst enemies.

Two major problems result from adoption of the sentencing table. Both were foreseeable on the basis of evaluation research concerning parole and sentencing guidelines and on the basis of the experience of earlier sentencing commissions. First, and most important, the effectiveness of guidelines systems depends on the willingness of officials to accept and apply them. In other words, they must be credible in the eyes of the officials who must use them. If the logic of a guidelines grid is not apparent on its face, if it looks mechanical and arbitrary, judges and others are likely to be alienated. In the sentencing policy literature this is referred to as the problem of the "sentencing machine." Judges and lawyers in sentencing believe their function is to impose fair, deserved, and appropriate punishments. Sentencing by use of a sentencing machine is the antithesis of this and a guideline grid that conjures up images of mechanical and arbitrary sentencing standards and processes foreseeably will alienate judges and others. ${ }^{7}$ Judges who are alienated from a sentencing guidelines system are unlikely to invest great effort in protecting the integrity of the system from efforts of lawyers and others to circumvent it.

The problem of the sentencing machine is not new. Partly because of it, state guidelines systems have many fewer offense-severity levels. Minnesota's felony guidelines have ten. Pennsylvania's guidelines, which also cover misdemeanors, have ten. Washington State considered adopting a 26level guidelines grid and rejected it in favor of a 14level grid. The rhetorical question was asked, "Could we plausibly explain to a judge why a level 16 crime is more serious than a level 15 crime?" When the Washington commission realized that it could not answer that question, it realized it had a sentencing-machine problem and opted for a smaller grid.

The second problem with a complicated guidelines system with an enormous sentencing grid is that there will foreseeably be high error rates in calculating guideline sentences. A major evaluation of four parole guideline grid systems showed that even simple grids produce significant levels of inaccurate guidelines calculations. ${ }^{8}$ Complicated grids produce high levels of calculation errors. That this problem affects the federal guidelines is shown by a recent Federal Judicial Center report on a project in which 47 federal probation officers were 


\section{COMMENTARY}

asked to calculate "base offense levels" for hypothetical defendants described in the sample cases used for discussion at the recent sentencing institute. for the Second and Eighth circuits. There were enormous differences in the offense levels calculated. ${ }^{9}$

Curiously, the Commission either did not know or did not care about the formidable foreseeable problems posed by creation of a sentencing machine. The Guidelines Introduction merely notes, "The Commission has established a sentencing table that for technical and practical reasons contains 43 levels." The technical reasons mentioned include a desire for overlapping guidelines ranges. No mention is made of the likely effects of the grid on judicial perceptions of the systems' wisdom or desirability, or of the foreseeable problem of high rates of error in guidelines application.

The sentencing-machine problem is, in principle, fixable. However, unlike the solutions to the first five problems discussed above, there is no solution that does not involve a substantial overhaul of the guidelines (this is also true of the mandatory penalties problem). To avoid the problems of the sentencing machine, the Commission will have to develop and promulgate a much smaller, facially more plausible grid.

A court could probably take judicial notice of the widespread hostility of judges and lawyers to the federal sentencing guidelines. The line that divides vehement critics from vocal proponents follows no pattern-it is not liberals versus conservatives, Republican appointees versus Democratic appointees, judicial activists versus adherents of judicial restraint. Partly this is because the guidelines have no vocal proponents except members of the U.S. Sentencing Commission and the U.S. Department of Justice. Partly it is because objections to the guidelines transcend ideological and partisan differences. The core objections are that the guidelines are too rigid and too harsh, and too often force judges and lawyers to choose between imposing sentences that are widely perceived as unjust or trying to achieve just results by means of hypocritical circumventions. Judges are forced by the guidelines to choose between their obligation to do justice and their obligation to enforce the law. Many judges resent having so often to make that choice. If the Commission would make the five simple changes recommended here, it would go a long way toward salvaging the guidelines. If it made the two somewhat more ambitious proposed changes, it might produce a system of guidelines that could command the support of judges and prosecutors and make far likelier the achievement of the purposes of the Sentencing Reform Act of 1984.

\section{FOOTNOTES}

${ }^{1}$ United States Sentencing Commission. December 1991. The Federal Sentencing Guidelines: A Report on the Operation of the Guideline System and Short-Term Impacts on Disparity in Sentencing, Use of Incarceration, and Prosecutorial Discretion and Plea Bargaining. Vol. 1, p. 85.

${ }^{2}$ U.S. Sentencing Commission. 1987. Supplementary Report on the Initial Sentencing Guidelines and Policy Statements. Washington, D.C.: U.S. Sentencing Commission.

${ }^{3}$ E.g., Federal Courts Study Committee. 1990. Report. Washington, D.C.: Federal Courts Study Committee, pp. 13343; Stephen J. Schulhofer and Ilene Nagel. 1989. "Negotiated Pleas Under the Federal Sentencing Guidelines: The First Fifteen Months," American Criminal Law Review 27:231-88.

${ }^{4}$ U.S. Sentencing Commission. 1991. Annual Report 1990. Washington, D.C.: U.S. Sentencing Commission. Table J.

${ }^{5}$ The major recommendation was to permit imposition of alternative sanctions for any offender having a minimum recommended guidelines sentence of 18 or fewer months. U.S. Sentencing Commission Alternatives to Imprisonment Project. 1990. The Federal Offender: A Program of Intermediate Punishments: Executive Summary. Washington, D.C.: U.S. Sentencing Commission.

${ }^{6}$ See, e.g., Martin Wasik and Andrew von Hirsch. 1988. "Non custodial Penalties and the Principles of Desert." Criminal Law Review 1988: 555-72; Norval Morris and Michael Tonry. 1990. Between Prison and Probation. New York: Oxford University Press.

${ }^{7}$ Alfred Blumstein, Jacqueline Cohen, Susan Martin, and Michael Tonry. 1983. Research on Sentencing: The Search for Reform. Washington, D.C.: National Academy Press, p. 159.

${ }^{8}$ Arthur D. Little, Inc. 1981. "An Evaluation of Parole Guidelines in Four Jurisdictions." Unpublished report prepared for the National Institute of Corrections.

9Pamela B. Lawrence and Paul J. Hofer. 1992. "An Empirical Study of the Application of Relevant Conduct Guideines. §1B1.3." Washington, D.C.: Federal Judicial Center. 